\title{
BEHAVIOUR OF ELASTOMERIC COMPOSITION WITH HIGH-DISPERSE CARBON ADDITIVES AT VARIOUS STEPS OF THE PROCESS
}

\author{
Vishnevskiy Konstantin Viktorovich \\ Candidate of Technical Sciences, Assistant, \\ Department of Technology of Petrochemical Synthesis and Polymer Materials Processing, \\ Belarusian State Technological University \\ Vik@belstu.by \\ Sverdlova St., 13A, 220006 Minsk, Republic of Belarus
}

\section{Shashok Zhanna Stanislavovna}

Candidate of Technical Sciences, Associate Professor, Department of Technology of Petrochemical Synthesis and Polymer Materials Processing, Belarusian State Technological University Vik@belstu.by Sverdlova St., 13A, 220006 Minsk, Republic of Belarus

\section{Prokopchuk Nikolay Romanovich}

Doctor of Chemical Sciences, Professor, Correspondent Member of NAS of Belarus, Chief Researcher, "Institute of Balneis" Republican Unitary Enterprise (Belarus) ntcarch1@yandex.ru Moskovskaya St., 267/2, 224017 Brest, Republic of Belarus

\begin{abstract}
The influence of a carbon nanomaterial obtained in a high-voltage discharge plasma on the endurance of elastomer compositions has been investigated. Complex tests of elastomeric compositions with highly dispersed carbon additives allowed us to confirm the model of nonlinear elastic deformation of macromolecules and adhesion between the elastomer and the nanoparticles. The results of these investigations comply with those obtained in determining the Mooney viscosity and relaxation, the parameters of the vulcanization kinetics of rubber mix, conventional tensile strength, relative breaking elongation of highly filled rubbers based on butadiene-nitrile caoutchoucs. To verify the assumed mechanism underlying the action of a carbon nanomaterial on elastomer compositions, the parameters of their vulcanizing network have been determined using the method of equilibrium swelling.
\end{abstract}

Key words: butadiene-nitrile caoutchouc, rubber, carbon nanomaterials, nanotubes, nanofibers, relaxation of rubber mix, elastic-hysteresis properties, vulcanization kinetics. 


\section{Introduction}

Performance requirements of rubber products is constantly increasing. This is due to the expansion of their area of application, and the tightening of the conditions of the use. Therefore, the research on various methods dealing with improving the properties of rubber and the mix formulations of elastomeric compositions is a promising direction. The adjustment of quantitative and qualitative content of ingredients allows improving the complex of technical properties of products without changing the design of equipment and technological methods of production. This leads to an increased use of composite materials with a complex structure involving components that have high dispersion ability.

Failure resistance, deformation and strength properties of the materials including nanomaterials have significantly determined by the inhomogeneity of their structure.

Mechanical properties of composite materials are determined by the interaction of the elastomer and fine components at the prase boundary.

\section{Experimental Part}

We investigated a filled elastomer composition based on butadiene-nitrile caoutchouc with a content of bound acrylonitrile of 1723 wt. \%. The high dispersion additives introduced into rubber mixtures ranged from 0.05 to $0.2 \mathrm{wt}$. parts per hundreds of caoutchouc. For comparison we used samples free from a nanoadditive. As a highly dispersed additives the fraction of the carbon nanomaterial (CNM) are used.

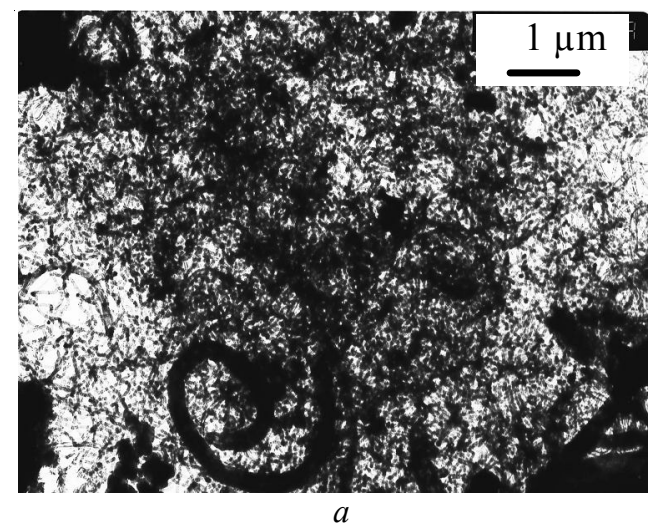

The starting carbon nanomaterial was obtained in a high-voltage discharge plasma, and then, after complex acid treatment and annealing, it was divided into fractions by ultrasound. The following fractions were used as additives to elastomer compositions: a "film" involving graphite and amorphous carbon particles, relatively large ranges of nanotubes and fibers, and a "suspension" consisting of separate carbon nanotubes with traces of other allotropical modifications.

Nanomaterial was obtained in plasma of the high-voltage charge. After complex processing by acids and annealing, by ultrasonic machining the material was divided into the following fractions: "film" which involve graphite particles, large tangles of tubes and fibers, and, "suspension" which separates carbon nanotubes (development of CNM began in HMTI of the NAS of Belarus. Now they are produced at the FPE "Promising Investigations and Technologies" (the city of Minsk) under the name of "ART-nano" specifications BY 690654933.001-2011). In Fig. 1 TEM - pictures of additives are presented.

The Mooney viscosity was determined with MV2000 viscometer, and tests were conducted employing the procedure similar to that recommended by the GOST 10722-76 standard and ASTM D1646-07. The parameters of the vulcanization kinetics were determined with the aid of an ODR2000 vibrorheometer in accordance with the State Standards GOST 12535-84. Crosslink density was measured by means of equilibrium swelling method. The test on the Rotorless Shear Rheometer (in accordance with ASTM D6601-02) was used for evaluating cure and dynamic property differences resulting from the use of carbon nanotubes in various dosages.

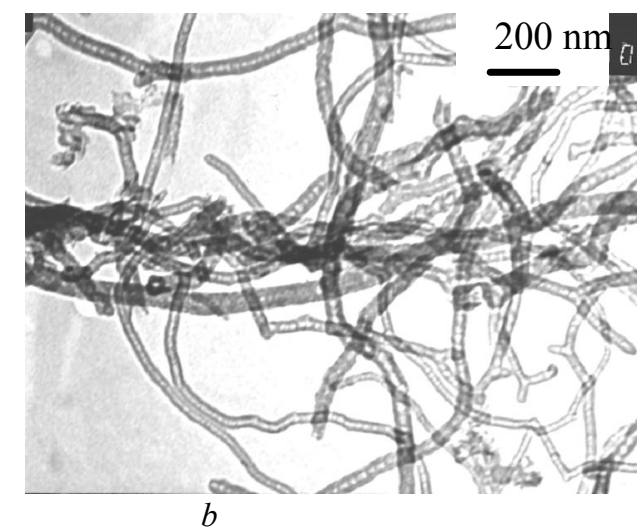

Fig. 1. TEM - pictures of the "film" $(a)$ and "suspension" $(b)$ fractions 
In the work the conditions of physical relaxation of tension of vulcanized stocks were also determined. Additionally, the method of dynamic indentation, allowed us to estimate the tangent of the mechanical loss. The essence of the method is striking with a stiff indenter on test material in a single pulse mode. After the electrical signal was recorded during impact, further it was converted into a chain of dependencies that allows obtaining physical and mechanical properties of the material upon impact. The method is implemented in the device "IPM-1K", developed at the Institute of Applied Physics of the National Academy of Sciences.

\section{Results and Discussion}

The rubber composition should provide a product with the specified performance characteristics and it still should be manufacturable at processing. The viscosity of the material determines the dynamics of the processing, it is a measure of material resistance to gradual deformation by shear stress or tensile stress. That parameter is a measure of the force which should be applied to the material for his flow at a given rate at various steps of the process [5]. Introduction of fine component will effect the plastoelastic properties of elastomeric compositions. It is difficult to estimate interaction between matrix and carbon nanomaterial and to determine the mechanism of this process. This is due to the fact that originally the composition contains a large amount of ingredients, and it is highly filled. Inactive carbon blacks with a particle size ranging from 9 to 320 microns are used.

The data obtained in the course of the tests (Table 1) indicate, that the introduction of carbon nanomaterials into elastomeric compositions based on butadiene-nitrile caoutchouc reduces the Mooney viscosity by $14 \%$. Minimum values of Mooney viscosity are observed in rubber mixtures containing fraction "suspension" in a dosage of $0.1 \mathrm{phr}$., containing "film" $-0.2 \mathrm{phr}$.

We analyzed the data obtained after tests on stress relaxation. It showed that samples of elastomeric composition having a minimum Mooney viscosity naturally characterized by a higher rate of stress relaxation. This is due to the increased segmental mobility of macromolecules in caoutchouc. Samples of rubber mixtures containing fraction "suspension" in a dosage of
$0.1 \mathrm{phr}$., have values of Slope and Relaxation coefficient totaled -0.417 and $51.7 \%$ (sample comparisons matter slope $=-0.386$ and $K_{r}=49.7 \%$ ). When addition fraction "film" in a dosage of $0.2 \mathrm{phr}$ the values of the indicators are slope $=-0.406$ and $K_{r}=50.8 \%$.

Table 1

Results of the tests of elastomeric compositions on Viscometer MV2000

\begin{tabular}{|l|c|c|c|c|}
\hline \multirow{2}{*}{$\begin{array}{c}\text { Fraction of } \\
\text { CNM }\end{array}$} & $\begin{array}{c}\text { Dosage, } \\
\text { phr. }\end{array}$ & $\begin{array}{c}\text { Mooney } \\
\text { viscosity, } \\
\text { Mooney } \\
\text { units }\end{array}$ & Slope & $K_{r}, \%$ \\
\hline $\begin{array}{l}\text { Without } \\
\text { additives }\end{array}$ & - & 57.3 & -0.386 & 49.7 \\
\hline \multirow{4}{*}{ "Film" } & 0.05 & 55.4 & -0.395 & 50.2 \\
\cline { 2 - 5 } & 0.10 & 53.1 & -0.400 & 51.0 \\
\cline { 2 - 5 } & 0.15 & 51.2 & -0.403 & 50.6 \\
\cline { 2 - 5 } & 0.20 & 50.1 & -0.406 & 50.8 \\
\hline \multirow{4}{*}{ "Suspension" } & 0.05 & 51.5 & -0.410 & 50.9 \\
\cline { 2 - 5 } & 0.10 & 49.5 & -0.417 & 51.7 \\
\cline { 2 - 5 } & 0.15 & 49.8 & -0.411 & 51.2 \\
\cline { 2 - 5 } & 0.20 & 49.9 & -0.405 & 50.8 \\
\hline
\end{tabular}

Notice. $K_{r}$ - relaxation coefficient, $\%$.

The authors $[3 ; 4]$ indicate that the linkage of macromolecules elastomeric matrix with filler is not absolutely rigid, and under shear loading the matrix (due to the "mobility" of the adsorption bond) is able to move along the surface of the particles. In the context of this hypothesis, the authors have made the structural model, which represents the two substrates (surfaces of adjacent particles) united by a spring (macromolecule) associated with the particles of the adsorption force (Fig. 2).

The geometry of the structural unit represents the following characteristics: $L_{\mathrm{o}}-$ length of spring, $D$ - length of the substrate and $L_{g}$ - the gap between the particles.

According to a structural model of the relaxation of the interaction of macromolecules elastomer nanomaterial particles decrease flow resistance of rubber compounds due to the fact that the interaction between the polar groups of acrylonitrile in the structure of macromolecules of caoutchouc is greater than the interaction between macromolecules of caoutchouc and CNM particles. As a result, nanotubes relief of molecular orientation in the direction of flow, which leads to a decrease in the Mooney viscosity of rubber mixtures and acceleration of the relaxation 


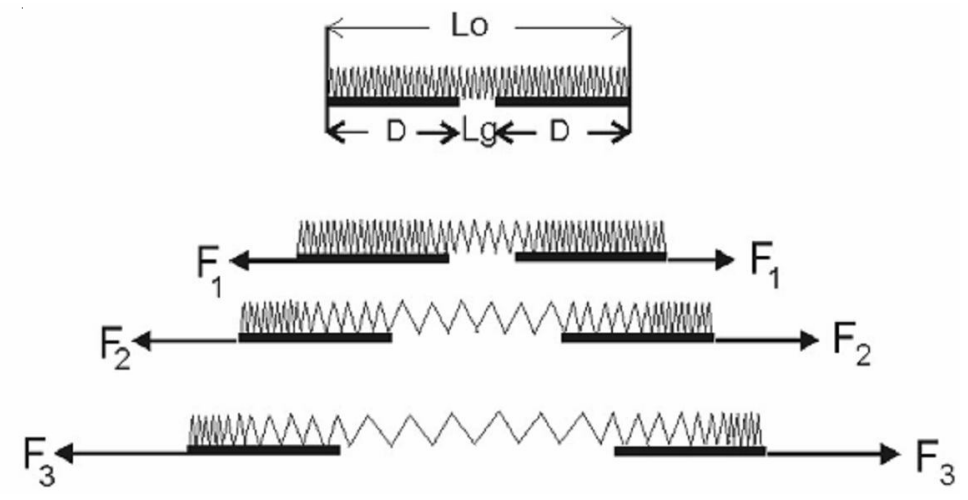

Fig. 2. The geometry of the structural unit of the model of the interaction of macromolecular and carbon nanomaterial particles

processes in the volume of the elastomeric matrix after removal of the load. The greatest change is observed in the relaxation properties of rubber compounds, which contains fraction "suspension", characterized by a more homogeneous structure.

Carbon nanomaterials have a large specific surface area and a functional group which may have impact not only on plasto-elastic properties of rubber compounds, but also participate in the formation of a spatial grid in curing process. In that process particles may interact with components of vulcanizing system and take part in formation of chemical and physical bonds at various steps of the process. Nature and structure of the vulcanization spatial grid defines a wide range of technical properties of elastomeric compositions. Results of the kinetics of vulcanization tests of rubber mixtures are presented in Table 2 .

Table 2

\section{Kinetics of vulcanization of investigated} rubber mixtures

\begin{tabular}{|l|c|c|c|}
\hline $\begin{array}{c}\text { Fraction } \\
\text { of CNM }\end{array}$ & Dosage, phr. & $t_{\mathrm{c}}(90), \mathrm{min}$ & $R_{h}, \mathrm{~min}^{-1}$ \\
\hline $\begin{array}{l}\text { Without } \\
\text { additives }\end{array}$ & - & 11.4 & 11.2 \\
\hline \multirow{3}{*}{ "Film" } & 0.05 & 11.0 & 11.4 \\
\cline { 2 - 4 } & 0.10 & 10.2 & 11.7 \\
\cline { 2 - 4 } & 0.15 & 10.1 & 11.5 \\
\cline { 2 - 4 } & 0.20 & 10.3 & 11.5 \\
\hline & 0.05 & 10.6 & 11.6 \\
\cline { 2 - 4 } & 0.10 & 10.0 & 11.8 \\
\cline { 2 - 4 } & 0.15 & 9.9 & 11.7 \\
\cline { 2 - 4 } & 0.20 & 9.7 & 12.0 \\
\hline
\end{tabular}

Notice. $t(90)$ - time for attaining the optimum vulcanization, $\min ; R_{h}$-vulcanization rate, $\min ^{-1}$.
Analysis of the vulcanization kinetics of elastomeric compositions based on the butadienenitrile caoutchouc with sulfuric vulcanizing system showed that the introduction of the carbon nanomaterial assists in reducing the time of attaining an optimum degree of vulcanization. In the case of the "suspension" fraction, there is almost a linear dependence of the time of attaining the optimum on the dosage of carbon nanomaterials (the lowest value is $9.7 \mathrm{~min}$ at $0.2 \mathrm{phr}$.), whereas in the case of the "film" fraction, the dependence is of extreme character with the inflection point at a fraction content of 0.15 phr. (10.1 min).

Vulcanizing system of the investigated samples of rubber mixtures includes a combination of accelerators: analogue of Accelerator MBTS and N,N'-diphenylguanidine (DPG). In the given case, the most probable is the surface interaction of nanoadditives with the polar components of the vulcanizing system (in particular, with DPG). It deactivation of the polar agent of the vulcanizing group by the particles of nanomaterials can occur, and its tendency to agglomeration or condensation decreases, thus favoring better dispersion of DPG within the mixture. Since in our case it is used as a secondary accelerator for the basic one MBTS, this favors a more intense, joint action of accelerators and of the vulcanizing system as a whole. That may affect the structure of the spatial grid of vulcanizates, which is confirmed by the change in the density of cross-linking (Fig. 3) and the temperature coefficient of linear expansion (TCLE) of vulcanizates (Fig. 4). 


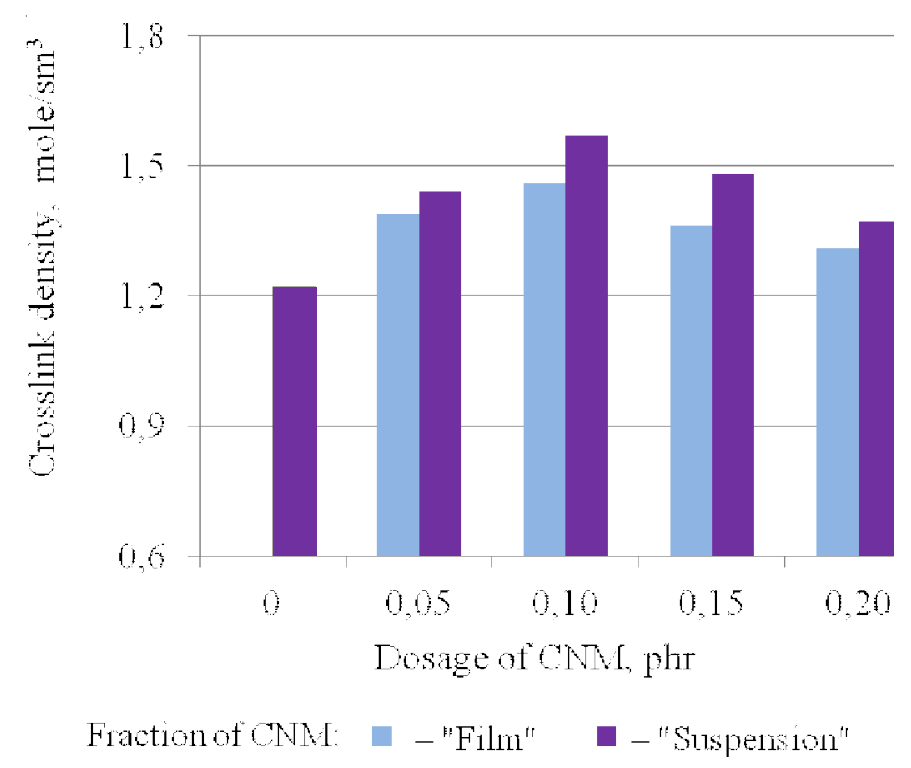

Fig. 3. Crosslink density of the vulcanizates
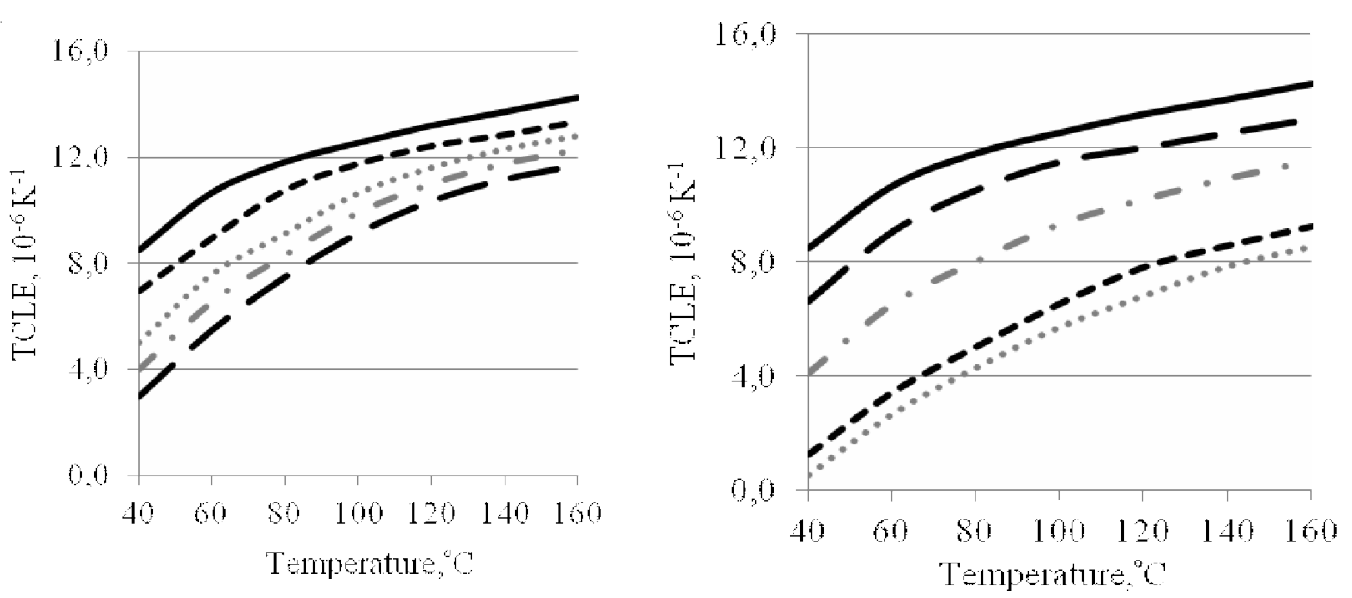

Dosage of CNM: — without additives, ---0.05 phr., ---- 0.1 phr., ..... 0.15 phr., - - 0.2 phr.

Fig. 4. The temperature coefficient of linear expansion of the samples with fraction "Film" $(a)$ and "Suspension" $(b)$

According to the obtained data, the application of the fractions "film" and "suspension" leads to an increase of $30 \%$ in concentration of crosslinks and thus reduces the values of the samples TCLE rubber in the temperature range of $(40 \pm 2) \div(120 \pm 2){ }^{\circ} \mathrm{C}$.

With increasing density of the spatial grid of the vulcanizate to an optimal value, the intermolecular interaction increases, that leads to an increase in modulus of internal friction and hysteresis of rubber [6]. Elastic-hysteresis property of the samples was estimated with a dynamic rheometer rotorless type RPA 2000 and device "IPM-1K" (Table 3).

The results obtained in testing the samples on an RPA 2000, show, that application of the fraction "suspension" of CNM leads to reducing of loss modulus, more than storage modulus one. This behavior of the rubber, is probably due to the participation of the nanotubes in the relaxation, load distribution and temperature in the bulk of the sample. It results in reduction of the local overstress and overheating in the volume of the elastomeric matrix. Therefore, the 
Elastic-hysteresis property of the samples

\begin{tabular}{|l|c|c|c|c|c|}
\hline Fraction of CNM & $\begin{array}{c}\text { Dosage, } \\
\text { phr. }\end{array}$ & $\operatorname{tg}$ д & $G,, \mathrm{kPa}$ & $G^{\prime}, \mathrm{kPa}$ & $\operatorname{tg}_{d}$ Д \\
\hline Without additives & - & 0.157 & 2502 & 394.1 & 0.173 \\
\hline \multirow{4}{*}{ "Film" } & 0.05 & 0.154 & 2450 & 377.3 & 0.177 \\
\cline { 2 - 6 } & 0.10 & 0.156 & 2445 & 380.9 & 0.183 \\
\cline { 2 - 6 } & 0.15 & 0.159 & 2430 & 386.1 & 0.197 \\
\cline { 2 - 6 } & 0.20 & 0.162 & 2435 & 396.2 & 0.190 \\
\hline \multirow{3}{*}{ "Suspension" } & 0.05 & 0.159 & 2434 & 394.2 & 0.168 \\
\cline { 2 - 6 } & 0.10 & 0.151 & 2252 & 339.5 & 0.161 \\
\cline { 2 - 6 } & 0.15 & 0.140 & 2221 & 315.2 & 0.163 \\
\cline { 2 - 6 } & 0.20 & 0.142 & 2230 & 314.1 & 0.167 \\
\hline
\end{tabular}

Notice. $\operatorname{tg} \delta$ - tangent of the angle of mechanical losses determined on the RPA 2000; $G$ ' - loss modulus, kPa; $G$ " - storage modulus, $\mathrm{kPa} ; \operatorname{tg}_{d} \delta$ - tangent of the angle of mechanical losses determined by method of dynamic indentation.

dependence of the $\operatorname{tg} \delta$ from the dose of the fractions CNM has an extreme behavior. The rubbers containing 0.15 and $0.2 \mathrm{phr}$. have the minimum value of $\operatorname{tg} \delta$ from 0.140 to 0.142 . Addition of "Film" fractions allows us to increase slightly (less $3 \%$ ) tangent of the angle of mechanical losses value. Similar dependences were obtained in tests on the device IPM-1K $\left(\operatorname{tg}_{d} \delta\right)$.

\section{Conclusions}

Thus, complex tests of elastomeric compositions with highly dispersed carbon additives allowed us to confirm the model of nonlinear elastic deformation of macromolecules and adhesion between the elastomer and the nanoparticles. Introduction of the additives leads to lower viscosity and increases the relaxation rate of elastomeric compositions. This can be explained by orientation facilitation of the macromolecules to each other. Furthermore, additives interact with the components of mixtures in the processing and during the vulcanization process. This is probably due to the interaction of the functional groups of the additives and ingredients of vulcanization system. This assumption is confirmed by the reduction of the time of attaining an optimum degree of vulcanization by $15 \%$, increase in the density of the crosslinking more than $20 \%$ and the change in the elastic-hysteresis properties of elastomeric compositions. The studies revealed a complex and multi-stage mechanism of interaction between carbon nanoadditives and components of elastomeric compositions.

\section{REFERENCES}

1. Avdeychik S.V., et al. Nanocomposite Materials Engineering: the Experience of Development and Application: Monograph. Grodno, GrSU Publ., 2006. 403 p. (in Russian).

2. Baron A.A., Bakhracheva Yu.S. The Method for Lifetime Estimation Through the Mechanical Properties in Tension. Mechanika (Kaunas), 2004, no. 3, pp. 29-32.

3. Evlampieva S.E, Moshev V.V. Specific Features Reinforcing Action of Nanoparticles in the Elastomer Matrix. Current Problems of Flow Mechanics: Abstracts of Scientific Conference (Perm, November 1-2, 2005). Perm, 2005, pp. 43-45. (in Russian).

4. Moshev V.V., Evlampieva S.E. Structural Modeling of the Time Dependence of Elastomer Composites Filled With Nanoparticles. Mechanics of Composite Materials and Structures, 2007, vol. 13, no. 3, pp. 400-407. (in Russian).

5. Shutilin Yu.F. Handbook on Properties and Applications of Elastomers: Monograph. Voronezh, Voronezh State Technological Academy Publ., 2003. 871 p. (in Russian).

6. Zhovner N.A., et al. Structure and Properties of Materials Based on Elastomers: Tutorial. Omsk, Branch RosZITLP Publ., 2003. 276 p. (in Russian). 


\section{ПОВЕДЕНИЕ ЭЛАСТОМЕРНОЙ КОМПОЗИЦИИ \\ С ВЫСОКОДИСПЕРСНЫМИ УГЛЕРОДНЫМИ ДОБАВКАМИ НА РАЗЛИЧНЫХ ЭТАПАХ ПРОЦЕССА}

\section{Вишневский Константин Викторович}

Кандидат технических наук, ассистент,

кафедра технологии нефтехимического синтеза и переработки полимерных материалов, Белорусский государственный технологический университет

Vik@belstu.by

ул. Свердлова, 13А, 220006 г. Минск, Республика Беларусь

\section{Шашок Жанна Станиславовна}

Кандидат технических наук, доцент,

кафедра технологии нефтехимического синтеза и переработки полимерных материалов, Белорусский государственный технологический университет

Vik@belstu.by

ул. Свердлова, 13А, 220006 г. Минск, Республика Беларусь

\section{Прокопчук Николай Романович}

Доктор химических наук, профессор

член-корреспондент НАН РБ,

главный научный сотрудник,

РУП «Институт БелНИИС» (Беларусь)

ntcarch1@yandex.ru

ул. Московская, 267/2, 224017 г. Брест, Республика Беларусь

Аннотация. В статье исследовалось влияние углеродных наноматериалов, полученных в высоковольтной газоразрядной плазме, на эластомерные композиции. Комплексные испытания эластомерных композитов с высокодисперсными углеродными добавками позволили нам подтвердить модель нелинейно-упругого деформирования макромолекул и адгезии между эластомером и наночастицами.

Ключевые слова: бутадиен-нитрильный каучук, резина, углеродные наноматериалы, нанотрубки, нановолокна, релаксация резиновой смеси, упруго-гистерезисные свойства, кинетика вулканизации. 